\title{
WSPOMNIENIE \\ O Ks. JÓZEFIE ARCHUTOWSKIM
}

Ocenić prawdziwie człowieka, na którego patrzymy już dziś przez pryzmat śmierci i to śmierci tragicznej, nie jest rzeczą łatwą. Zwykle w takich wypadkach, skłonni jesteśmy do przesady, która częstokroć nie ma faktycznego pokrycia w rzeczywistości. Nie będzie to jednak przesadą, jeśli w stosunku do śp. Ks. Józefa Archutowskiego, osobowość jego streścimy w jednym zdaniu: Był pochodnią gorejącą i świecącą. Gorzał miłością Biblii i świecił w około siebie wspaniałym przykładem swego kapłańskiego żywota. Takie sa dwie zasadnicze cechy jego charakteru.

Urodził się 1 listopada 1879 r. we wsi Karolina (powiecie pułtuskim) koło Warszawy, studia gimnazjalne ukończył w Pułtusku i Suwałkach, a w r. 1898 wstąpił do Seminarium Duchownego w Warszawie. Wysłany po trzech latach na wyższe studia do Akademii w Petersburgu, ukończył ją w roku 1905 ze stopniem Magistra Teologii. W międzyczasie otrzymuje w roku 1904 z rąk Arcb. Szembeka święcenia kapłańskie i pełni obowiązki wikarego i prefekta: kolejno w Skierniewicach, Zgierzu i Łowiczu. Od r. 1907 przenosi się do Warszawy na stałe, by już całkowicie poświęcić się umiłowanym przez siebie studiom biblijnym. Dla pogłębienia swej wiedzy naukowej wyjeżdżał kilka razy za granicę, gdzie zapoznał się z największym biblistą ówczesnym 0 . Marią Józefem Lagrange'm. Postać tego głębokiego myśliciela i twórcy nowoczesnej egzegezy wywarła na nim niezatarte wrażenie, tak, że pozostanie jego wielbicielem aż do śmierci. W czasie swojej dwukrotnej podróży do Ziemi św. zatrzyma się przez kilka tygodni w klasztorze OO. Dominikanów, do którego należał O. M. J. Lagrange, co niektórzy, nie słusznie zresztą, uważali za chęć wstąpienia do tego zakonu. Sympatia do Dominikanów miała inne podłoże: wypływała z głębokiej i szczerej przyjaźni, jaka łączyła go z O. M. J. Lagrange'm. Ten ostatni także cenił wysoko Ks. Archutowskiego. Wyraził się kiedyś o nim: „Temu profesorowi nie można nic nowego powiedzieć, bo on czytał wszystko ${ }^{661}$ ). Ks. A. nie tylko czytał, ale $\mathrm{i}$ pisał, studiował $\mathrm{i}$ badał dużo $\mathrm{i}$ dzielił się wynikami swych prac z ogółem społeczeństwa, jużto na łamach pism kościelnych, już to $w$ oddzielnych monografiach.

1) Por. Przeglạd biblijny, Kraków 1958, s. 24. 
Nic więc dziwnego, że kiedy powstał Katolicki Uniwersytet Lubelski, pierwszy jego rektor Ks. Idzi Radziszewski powołał go na profesora Studium Biblijnego, jako znanego już wtedy biblistę. Na KUL'-u będzie jednak Ks. A. bardzo krótko, ponieważ już w r. 1920 (22 kwietnia) otrzyma nominację na Profesora Nadzwyczajnego Studium Biblijnego na Uniwersytecie Jagiellońskim.

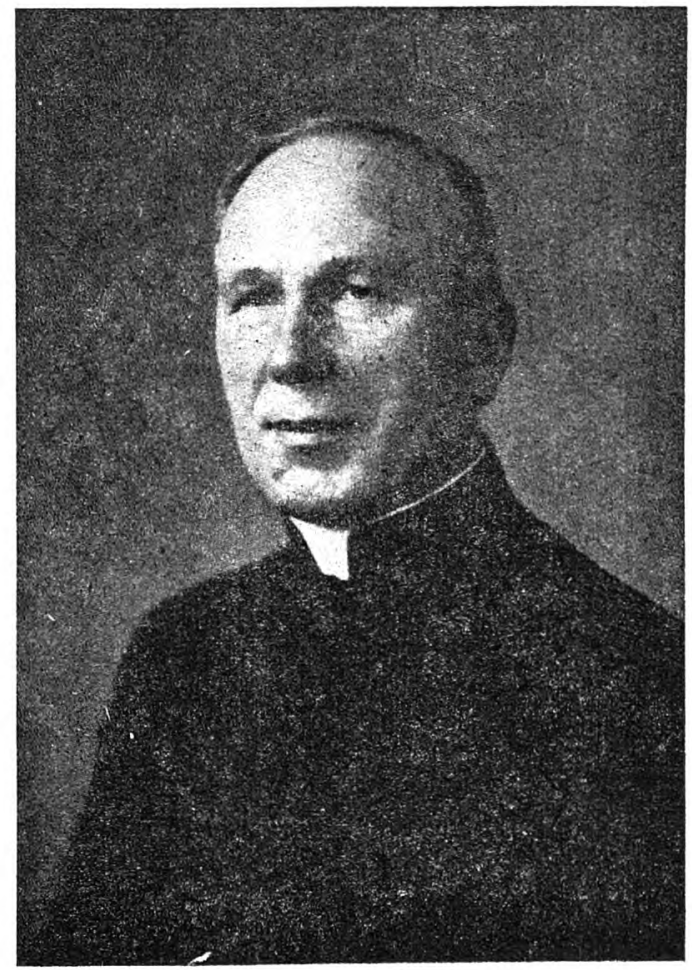

\section{Ks. JOZEF ARCHUTOWSKI}

Od tej daty rozpocznie się nowy okres w jego życiu, który jeszcze bardziej pogłębi jego zamiłowania biblijne i uwypukli niezwykłe zalety jego umysłu i serca. W dniu 11 września $1923 \mathrm{r}$. otrzymuje nominację na profesora zwyczajnego, potem będzie kilkakrotnym Dziekanem Wydziału Teologicznego i gorliwym jego opiekunem i protektorem. Przeżyje potężny wstrząs, kiedy wybuchnie wojna polsko-niemiecka i sam padnie jej ofiarą, aresztowany 6 listopada $1939 \mathrm{r}$. i osadzony w obozie koncentracyjnym 
w Sachsenhausen pod Oranienburgiem koło Berlina. Zwolniony z obozu 9 lutego $1940 \mathrm{r}$. nie traci ducha, ale organizuje tajne nauczanie w klasztorze Ks. Ks. Salwatorianów na Zakrzówku.

Tymczasem losem jego zainteresuje się Warszawa, która przez Ks. Zygmunta Choromańskiego, ówczesnego kanclerza, zaproponuje mu objęcie wakującego stanowiska proboszcza parafii Nawiedzenia Najśw. Marii Panny na Nowym Mieście. Po długich wahaniach i namysłach przyjmuje proponowane mu stanowisko i 30 maja $1943 \mathrm{r}$. odbywa uroczysty ingres do nowej parafii. W kilka dni potem zostaje mianowany kanonikiem gremialnym Kapituły Warszawskiej. Duszpasterzuje bardzo owocnie, lecz niestety tylko 15 miesięcy. bo ginie 31 sierpnia 1944 r. jako jedna z wielu ofiar powstania warszawskiego, zasypany gruzami w klasztorze SS. Sakramentek, gdzie przebywał w schronie. Zwłoki jego wydobyto w lipcu 1945 r. i złożono tymezasowo w katakumbach kościoła św. Karola na Powązkach. W r. 1947 Kapituła Warszawska urządziła mu uroczysty pogrzeb, składając jego śmiertelne szczątki na cmentarzu na Powązkach do wspólnej kapłańskiej mogiły, w której leży 36 ofiar wojny.

Ks. Archutowski, gdy zginął, liczył 65 lat. Założywsźy, że jako alumn warszawskiego Seminarium Duchownego rozpoczą z zamiłowaniem swoje studia nad Pismem św., możemy śmiało powiedzieć, że poświęcił mu pełne 45 lat swego życia. Zasługa jego przeogromna leży nie w tym, że dużo pisał, a jeszcze więcej czytał o Piśmie św., ale że w ogóle odważył się poświęcić swe życie tym zagadnieniom, które w Polsce od czasów Ks. J. Wujka leżały w ogóle odłogiem. Ks. A. jest pierwszym biblistą polskim, którego cechuje wielka nowoczesność poglądów. Wysoką pozycję biblijną zdobył sobie przez swoje podręczniki do studium biblijnego i przez specjalne szczegółowe monografie. Na uwage z podręczników zasługują trzy prace: Wstęp szczegótowy do Ksiag św. Starego Testamentu, Kraków 1927 r., O natchnieniu Pisma świętego, Kraków 1930 i Historia i Krytyka tekstu hebrajshiego Starego Testamentu, Kraków 1938. s

Zaletą jego wstępu jest to, że zestawia bardzo bogaty materiał, zarówno podawany przez egzegetów katolickich, jak protestanckich, radykalnych jak i konserwatywnych, podając zawsze pod koniec każdego rozdziału syntezę własnych myśli. 
W układzie treści nie jest autor oryginalny, wzorował się bowiem całkowicie na takiej samej pracy Prof. J. Nikla ${ }^{2}$ ).

Kwestię natchnienia Pisma św. opracował Ks. A. częściowo oryginalnie. Zawsze twierdził, że nie może być dobrym biblistą ten, kto nie zdaje sobie sprawy z tego, jaką ksiegą jest Pismo św. Sw. Grzegorz Wielki pisze, że jest ono „listem Wszechmocnego Boga do swego stworzenia“, a Sobór Watykański wyrazi się o księgach świętych, że „Spiritu Sancto inspirante conscripti, Deum habent auctorem". Poza te orzeczenia Kościół nigdy dalej nie pójdzie. Ale pójdą teologowie szczególnie wtedy, gdy w drugiej połowie XIX w. kwestia natchnienia stanie się aktualna, Kiedy cały obóz radykalnych egzegetów przypuści szturm na świętość ksiąg natchnionych i będzie starał się zerwać z nich aureolę świętości i zniżyć je do rzędu zwykłych ksiąg, wtedy bibliści katoliccy staną w obronie Pisma św. Będą bronić zaciekle natchnienia i dlatego wpadną w szereg nowych definicji, podziałów i dystynkẹii, które w konsekwencji swojej zamiast wyjaśnić istotę zagadnienia wprowadza pewne zamieszanie. I dlatego z początkiem XX wieku głęboko myślący egzegeci katoliccy rzucą twierdzenie, że potrzeba nam obecnie nowej definicji natchnienia, która by odpowiadała potrzebom chwili. Ks. A. stanie w ich szeregu. Nie zadowoli się podziałem na natchnienie zewnętrzne, czy wewnętrzne, pozytywne czy negatywne, czy też na elementum materiale $i$ formale w natchnieniu. Wspomni o tym w swej pracy, ale tylko dlatego, by nie zasłużyć sobie na zarzut, że nie zna zagadnienia w całości. Sam postawi tezę, że natchnienie należy do dziedziny łaski, dokonało się w głębi duszy autorów i wobec tego nie możemy się domagać, mówiąc o nim, żadnych dowodów, czy sprawdzianów zewnętrznych. W natchnieniu nie można oddzielać tego, co popochodzi od Boga, od tego co pochodzi od człowieka, albowiem istnieje w nim jeden wspólny czynnik bosko-ludzki, sprawiający, że każda księga i całe Pismo św. jest wspólnym dziełem, napisanym równocześnie przez Boga i przez człowieka.

Największą jednak sławę biblisty i uczonego zyskał sobie Ks. A. przez trzeci swój podręcznik ,Historia i Krytyka tekstu Hebrajskiego Starego Testamentu". Jest to praca w części zestawiająca wyniki najnowszych badań nad pismem i językiem hebraj-

2) Por. J. Nikel, Grundriss der Einleitung in das Alte Testament, Münster i. W. 1924 . 
skim, w części zaś podająca propozycje autora, odnośnie do krytyki samego tekstu. Dawno już bibliści polscy tęsknili do takiego dzieła. Wprawdzie egzegeci zagraniczni poruszali często te zagadnienia $w$ swoich pracach, ale traktowali je fragmentarycznie. Bauer i Leander ${ }^{3}$ ) w swojej gramatyce omawiają historię języka hebrajskiego, Fr. Delitzsch ${ }^{4}$ ) porusza zagadnienie błędów w samym tekście, L. Dennefeld ${ }^{5}$ ) rozwija przed czytelnikiem koleje. jakie przechodziły w ciągu' 20 wieków poszczególne teksty ksiąg świętych, żaden jednak z nich nie daje syntezy powyższych zagadnień. Czyni to Ks. A. w swojej pracy. Słusznie zatem wyraził się o niej O. K. Smoroński ${ }^{6}$ ): „Studium to przynosi zaszczyt nie tylko autorowi, ale w ogóle nauce polskiej, gdyż i w zagranicznej literaturze, zwłaszcza katolickiej, nie ma tak dobrej pracy $w$ tej materii. Nie powstydzilibyśmy się i za granicą, gdyby to dzieło zostało przetłumaczone na języki obce ${ }^{6 .}$. Wspomnę także o gramatyce hebrajskiej, napisanej przez Ks. Archutowskiego, której dziś jeszcze studenci używają ${ }^{\top}$ ).

Równocześnie przy pracy nad podręcznikami opracowywał Ks. A. szczególowe zagadnienia biblistyki. Pasjonowała go kwestia przekładów Pisma św. na język polski, zdawał sobie sprawę z tego, że ogół społeczeństwa może czytać Biblię tylko w języku ojczystym. Taką była tylko Biblia Ks. J. Wujka. Zasługa Ks. A. jest to, że wydobył Biblię Ks. Wujka z lamusa historii, do której zaczynała już schodzić, i zwrócił uwagę na nieprzemijające jej wartości. Zamiłowanie Ks. A. do Biblii Ks. Wujka było tak wielkie, że założył w 1907 roku specjalne "Polskie Towarzystwo wydawania Pisma św. pod wezwaniem Ks. J. Wujka“. Zadaniem tego Towarzystwa było rozszerzanie Biblii Wujkowej wśród społeczeństwa i praca nad odnowieniem jej tekstu. Celem tego odnowienia było uczynienie Wujka zrozumiałym dla szerszego ogółu wiernych. Ks. A. w swoim artykule „Odnowienie tekstu Wujkowego $i$ nowe przeklady ksiag świętych", zarzucał Biblii Wujkowej trzy braki: 1) Po trzech wiekach tekst Wujka okazał się w wielu miejscach całkowicie niezro-

3) Bauer-Leander, Historische Grammatik der hebr. Sprache. Halle a. S., 1918.

4) Fr. Delitzsch, D'e Lese und Schreibfehler im A. Test. nebst den einverleibten Randnoten klassifiziert, Berlin 1920.

5) Dennefeld. Histoire des livres de l'Ancien Testament, Par's 1929.

6) Por. Homo Dei, 1938. s. 259.

') I Wyd. w r. 1908, II Wyd. 1925. 
zumiałym, oczywiście nie z winy samego tłumacza, lecz ze względu na szereg wyrazów, które wyszły całkowicie z użycia lub zmienily już dziś swoje pierwotne znaczenie; 2) Komentarz, pisany przez Wujka do jego Biblii na skutek rozwoju nauk biblijnych okazał się już prawie zupełnie nie wystarczającym, trzeba go zatem uzupełnić najnowszymi zdobyczami nauk biblijnych; 3) Wiadomo, że Ks. J. Wujek tłumaczył z Wulgaty Klementyńskiej, wydanej w r. 1592, i chociaż ona wtedy była najpoprawniejszym tekstem Wulgaty w ogóle, to już dziś mamy lepsze wydania tekstu. Stąd zrodziła się potrzeba wniesienia do samego tekstu Wujka nowych istotnych poprawek. Widzimy z tego, że uwagi Ks. A. sa słuszne i trafne, a najważniejsze to, że nie zrywają z tekstem Ks. Wujka, tylko proponują pewne poprawki. Poprawki wprowadził sam Ks. A. w czyn, żeby nie być gołosłownym, w Poznańskim wydaniu Pisma św., gdziè w IV tomie opracował księgi Prorockie i Machabejskie. Zasadniczo będzie Ks. A. przeciwnikiem wszelkich, choćby najmniejszych poprawek tekstu Ks. J. Wujka. Wyrazi się nawet:, „wolałbym, aby tekst Wujkowy pozostał bez poprawiań i zmian, nawet pod względem językowym... aby wydawano go tak, jak się wydaje dzieła autorów XVI i XVII stulecia ${ }^{48}$ ). Okazuje się tu Ks. A. jako niezwykły wielbiciel i obrońca tekstu Wujkowego. I chociaż z biegiem czasu zainteresowania jego naukowe z konieczności przerzuca się na inne pola biblistyki, to przecież często będzie nawracał do tekstu Wujkowego, aż w końcu widząc szereg różnych wydań Biblii Wujka, w różny sposób zniekształconych, sam wyda w r. 1937 „Cztery Ewangelie“住, nawracając prawie zupełnie do tekstu Wujkowego.

Z innych zagadnień, związanych z biblistyką, interesowała go kwestia prawdziwości Pisma św. i jego zgodności z wynikami nauk przyrodniczych. W tych Ks. A. nie był oryginalny, ale poszedł za tezą swego mistrza $O$. Lagrange'a. Nie jest to wcale żadną ujmą dla niego, ale raczej zaletą, że naukę myśliciela francuskiego przeszczepił na teren polski. Przyjąć bowiem poglądy O. L. było rzeczą bardzo ryzykowną, ponieważ należał on do tej grupy uczoñych, których poglądy nie zawsze spotykały się z aprobatą teologów konserwatywnych. W prawdzie żadne z dzieł O. L. oficjalnie nie było potępione, jednakże wszystkie wybiegały swoją oryginalnością

8) Ks. J. Archutowski, Uwagi o nowych wydaniach Pisma św., Kraków, 1936, s. 12. 
i ciekawością poglądów kilkadziesiąt lat naprzód. Ks. Archutowski szybko podchwycił te poglądy, dzielił się nimi ze swoimi słuchaczami, przerabiał i uzupełniał swymi pomysłami, a w końcu ogłaszał drukiem. Z tego okresu pochodzą jego prace, takie jak „Historyczność Potopu", artykuł w Ateneum Kapł., Włocławek 1931, „Proteewangelia“", art. tamże 1933, „Kosmogonia Biblijna“ Kraków 1934 i inne.

W poglądach swoich biblijnych Ks. A. konserwatystą nie był. Nie był też racjonalistą, chociaż miał i znał wszystkie dzieła radykalnych egzegetów. Cechowała go nowoczesność poglądów, którą umiał pogodzić z nauczaniem Kościoła. Te poglądy jego całkiem nowoczesne, a równocześnie nacechowane głęboką wiarą, wyraził Ks. A. w swej pracy „Monoteizm izraelski i jego geneza“", wydanej w Krakowie 1924 r. Jest to praca pod pewnym względem informacyjna, ale zawiera i nowe poglądy autora. Ideą przewodnią tego dzieła jest wykazać na faktach i przykładach z życia narodu wybranego niezwykła opiekę Wszechmocnego Boga nad nim, a tym samym udowodnić, że Pismo św., które te fakty opowiada, nie może byé zwykłą i pospolitą księga i nie można jej stawiać na równi z dziełami autorów klasycznych.

Pismo św. jest boską księgą. Szczególnie ten boski charakter ksiąg św. podkreślił Ks. A. pod koniec swego życia, kiedy zainteresowania jego skupiały się przede wszystkim na prorokach i psalmach. Przez kilkanaście lat opracowywał tekst i komentarz do księgi Izajasza, ciesząc się, że po wojnie będzie mógł go ogłosić drukiem. Na krótko przed śmiercią przygotował również do druku „Teologie Księgi Psalmów" i miewał już jako proboszcz warszawski na ten temat wykłady do tamtejszej inteligencji. Niestety obie rzeczy w manuskrypcie spaliły się w czasie powstania warszawskiego, zachował się jedynie odpis manuskryptu „Teologii Psalmów" i jest dziś własnością SS. Sakramentek, gdzie Ks. A. spędził ostatnie chwile swego życia.

Praca jednak Ks. A. jako biblisty nie ograniczała się tylko do pisania i ogłaszania drukiem swoich poglądów. Wyrażał je także w czasie swoich wykładów i w gronie starszych i młodszych kolegów. Jako wykładowca specjalnie nie przyciagal do siebie młodzieży, albowiem daru wymowy porywającej i przykuwającej do siebie słuchacza nie miał. Brak ten jednak uzupełniał ogromem wiedzy, solidnością przygotowania i pewnością nauczania. Kto go słuchał, 
odczuwał od razu, że ma przed sobą człowieka, który nie lekceważy słuchacza, ani słów na wiatr nie rzuca. Zawsze spokojny, pełen powagi, imponował swoją osobowością. Bo też miał czym imponować. Był człowiekiem o szerokich horyzontach. Planował zawsze na kilkanaście lat naprzód. Chciał, by Pismo św. kochały i znały nie tylko współczesne, ale i przyszłe pokolenia. Aby to osiągnąć, założył „K oło $\mathrm{B}$ i b l is tó $\mathrm{w}^{6}$, zorganizował „Pierwszy zjazd Biblistów Polskich" i był twóreą t. zw. "Klubu młodych księży".

Koło Biblistów jest organizacją studentów Uniw. Jagiellońskiego i istnieje do dnia dzisiejszego. W dniu 31 stycznia $1925 \mathrm{r}$. na konstytucyjnym zebraniu tego Koła przedstawił Ks. A. zebranym pobudki, jakie nim kierowały przy zakładaniu tej organizacji. ,Zadaniem każdego profesora - powiedzial - jest rozbudzenie ruchu naukowego; chcąc tego dokonać, trzeba zjednoczyć siły. Ruch teologiczny w Polsce jest bardzo słaby i powinniśmy starać się go rozbudzić. Tu w Kółku naszym mamy się zaprawiać do pracy systematycznej, a na stanowiskach takich czy innych już na własną ręke posuwać naprzód ruch teologiczny. To postulat najważniejszy ${ }^{6{ }^{9}}$ ). "Koło Biblistów ${ }^{66}$ realizowało ten postulat swego założyciela zawsze. Wyrazem tej realizacji są liczne publikacje Koła z dziedziny biblijnej, zarówno naukowe jak i popularne. Prace swoje i plany na przyszłość omawiało Koło Biblijne bądź to na zebraniach Zarządu, bądź na zebraniach plenarnych, na których mimo nawału pracy zawsze był obecny Ks. A., jako Kurator Koła.

Koło Biblistów obejmowało jednak tylko studentów teologii, którzy właściwie biblistami nie byli, a zatem nie mogli wpłynąć na rozwój nauk biblijnych w Polsce. Mogli zaś to zrobić sami Profesorowie - bibliści. Trzeba było zatem porozumieć się z nimi i wytyczyć nowy kierunek pracy. Uczynił to Ks. A., organizując „Pierwszy Zjazd Biblistów Polskich" przy współudziale Ks. Prof. P. Stacha i Ks. Prof. Fr. Rosłańca. Zjazd ten odbył się 31 marca i 1 kwietnia 1937 r. w Krakowie ${ }^{10}$ ). Celem zasadniczym zjazdu było zastanowić się i powziąć konkretne postanowienia w sprawie wydania nowego przekładu Pisma św. na język polski. Postanowienie powzięto.

„Nowy przekład Pisma św. - mówił na zjeździe Ks. Bp. Kubina - musi byéc ${ }^{66}$, Ks. Archutowski dodał w imieniu wszyst-

9) Por. Kisega protokółów zebrań Koła Biblistów, s. 1.

10 Por. Ks. Piotr Stach, Pierwszy zjazd biblistów po'skich w Krakowie, art. w Collectanea Theologica XVIII, 1937. 
kich: ,,i będzie, bo wierzę mocno w dobrą i szczerą wolę tych, którzy współpracę przyobiecali ${ }^{611}$ ). Niestety, nikt nie przeczuwał, że wybuchnie wojna, która pokrzyżuje wszystkie plany.

Ks. A. nie był biblistą o egoistycznym nastawieniu. Pismem świętym chciał zainteresować ludzi wszelkiego wieku i stanu. Dlatego założył specjalnie dla młodszych księży t. zw. „klub młodych“, których zbierał u siebie przeważnie raz w tygodniu i dyskutował z nimi najbardziej aktualne zagadnienia z teologii i ze świata. Mimo licznych zajęć znalazł także czas na bardzo absorbującą czynność, a mianowicie na wydawanie specjalnego czasopisma biblijnego. Rozpoczął wydawać „Przegląd Biblijny“ na wzór francuskiego „Revue Biblique ${ }^{6 .}$. Czasopismo to wychodziło stosunkowo bardzo krótko, bo zaledwie trzy lata (wojna przerwała jego rozwój), ale daje chlubne świadectwo swemu Redaktorowi, który właściwie był jego główną sprężyną. Pisywał w każdym numerze artykuły, recenzje, prowadził korekty, a nawet $\mathrm{w}$ wielu wypadkach zajmował się sam wysyłką pisma.

Praca biblijna nie przesłaniała mu widoku na inne dziedziny życia. Interesowało go wszystko: Biblistyka, teologia, literatura, humanistyka, a nawet praca społeczna. Utrzymywał ścisły kontakt z profesorami świeckimi i uczonymi, od których wiele zyskiwał, ale i którym w zamian za to wiele dawał.

Siłę do pracy nad tym wszystkim czerpał ze swojego wnętrza. Był kapłanem bez cienia, naprawdę ,verus Israelita“. Prosty, pokorny, w rozmowie naturalny, nie dawał nawet poznać po sobie, że piastuje zaszczytną godność profesora Uniwersytetu. Chociaż pochodził z W Wrszawy, nigdy nie podkreślał tego. ,W Wzedł między nas - mówił o nim Ks. Piwowarczyk - jako jeden z nas". Z głębokim skupieniem odprawiał zawsze Mszę św. Nigdy nie opuszezał przygotowania i dziękczynienia po niej. Wieczorem można go było często zastać z różańcem w ręku. Chętnie darowywał ludziom przykrości i zapominał o krzywdach, jakie mu wyrządzili. Był człowiekiem o wielkiej pogodzie ducha, a nawet bardzo wesołym. Lubił wokoło siebie nastrój pogodny i żartobliwy. Ale też umiał bez trudu stać się poważnym i skupionym. Wtedy wydawał się dziwnie silny, jakby niedostępny, a w postanowieniach niezłomny. A przy tym wszystkim był niezwykle pokornym. W testamencie swoim napisze o sobie: „Mało, zbyt mało Pana mego miłowałem, a wielu

11) Por. Przegląd Biblijny, 1937, s. 108. 
występkami Go obraziłem, za co Go szczerze przepraszam i całym sercem żałuję $e^{66}$. Źródłem takiego jego charakteru i duchowego usposobienia była zawsze żywa dziecięca pobożność, wiara i miłość Boga.

S̄p. Ks. Archutowski umarł sześć lat temu. W pamięci naszej jednak żyje i żyć będzie nadal przez swoje czyny, prace i daleko naprzód wybiegające zamiary ${ }^{12}$ ).

Kraków

Ks. STANISEAW GRZYBEK

\section{OSOBOWOŚĆ PEDAGOGICZNA CHRYSTUSA}

I. Chrystus ,jedynym Nuuczycielem".

Już Sokrates był zdania, że w kwestiach najważniejszych zagadnień bytu ludzkiego rozum nie może być jedynym miarodajnym światłem. Stąd pochodzi nieodzowna konieczność zstąpienia samego Boga na ziemię, na którejby żywym słowem i przykładem życia nauczył prawdziwej sprawiedliwości. Poglądy Sokratesa podzielał jego uczeń Platon. W powyższych problemach dwie miał do wyboru drogi. Pierwszą, na którejby sam gruntownie mógł zbadać, jak postępować należy, a jeśliby to było niemożliwe, musiałby wejść na drugą drogę, oparcia się na miarodajnym w tych sprawach autorytecie. Wiara w rozum utalentowanych jednostek może przysporzyć pewnej poręki na bezpieczne przepłynięcie przepastnego oceanu życia. Niemniej jednak bezpieczniej i pewniej odbywa się podróż po wzburzonych falach życia, gdy łódź życia jest w swych częściach bardziej zwarta, trwalsza i odporniejsza przeciwko porywistym i burzliwym wichrom i nawałnicom. Doznaje zaś wzmocnienia wtedy, gdy się człowiek oprze w swych tendencjach życiowych na jakimś objawieniu Bożym (Logon theiov tinos diaporevthenai - Symposion).

Myśli największych mędrców świata hellenistycznego o ponadświatowym nauczycielu znalazły swe potwierdzenie i uzasadnienie $\mathrm{w}$ księgach Starego Testamentu. Prorocy z bezwzględną pewnością przepowiedzieli, iż przyobiecany Mesjasz zstąpi na ziemię. Nie człowiekiem tylko, ale i Bogiem będzie (Iz. 40, 9), Ojcem przyszłego wieku $(9,6)$. Światłością narodom $(42,6)$, Światłością wielką mieszkającym w krainie cienia śmierci $(9,2)$, Przyjacielem ubogich i chorych $(25,4)$, Wodzem i Nauczycielem narodom $(55,4)$ i dobrym Pasterzem (Iz. 40, 11; Jer. 31, 10).

12) Wspomnienie to zostało odezytane na uroczystej akademii żałobnej, która ku czci ks. Archutowskiego urządził Wydział Teolog. U. J. w auli uniwersyteckiej dnia 18 marca $1950 \mathrm{r}$. 